\title{
Optimizing sterilization conditions and growth regulator effects on in vitro shoot regeneration through direct organogenesis in Chenopodium quinoa
}

\author{
MoHSEn Hesami *, RoOHANGiz NADERI, MoHSEn YoosefZADEH-NaJAFABadI \\ Department of Horticultural Science, University of Tehran, Karaj, Iran
}

\begin{abstract}
Chenopodium quinoa Willd. is known as a multipurpose crop that could be employed as an alternative on unsuitable lands with limited water resources such as arid and semi-arid regions. However, the biggest problem in cultivating this plant is contamination by viruses that are carried by quinoa seeds and cause diseases. Therefore, in vitro propagation methods could be applied to produce virus-free plants. The capacity of sodium hypochlorite to sterilize seeds and the regeneration potential of cotyledonary node segments were studied on Murashige and Skoog (MS) medium consisting of various concentrations of cytokinins and auxins either alone or in combinations. Although no contamination was observed after sterilization with $20 \%$ sodium hypochlorite and 10 and 15 min of immersion; with $25 \%$ sodium hypochlorite and 5, 10, and 15 min of immersion, the highest seed germination (100\%) was obtained after sterilization with $20 \%$ sodium hypochlorite for 5 minutes. MS medium supplemented with $2.0 \mathrm{mg} / 1$ 6-benzylaminopurine (BAP) had the highest shoot induction frequency (93.33\%) with an average of 4.96 shoots per node explant. This study is the first report of an appropriate and effective in vitro regeneration protocol for Chenopodium quinoa via direct organogenesis through cotyledonary node explants derived from axenic-seedlings, which can be effectively employed for the genetic manipulations and exploitation of active biomolecules of this valuable plant. This protocol can also increase the speed of quinoa breeding programs.
\end{abstract}

Key words: cotyledonary node, sterilization, sodium hypochlorite, proliferation, plant growth regulations

\section{Introduction}

Quinoa (Chenopodium quinoaWilld.) is an indigenous pseudo-cereal of the Andean region that belongs to Chenopodiaceae family. There are more than 3000 species of quinoa that can be grouped into five separate ecotypes covering different altitudes of the Andes, namely the Yungas, Salares, Inter-Andean Valley, highlands and coastal/lowlands (Hu et al., 2017). Quinoa is also known as an important source of food in ancient Columbian cultures in Latin America (González-Teuber et al., 2017). There is some evidence demonstrating that this plant was domesticated over 5000 years ago (Sosa Zuniga et al., 2017). The leaves and seeds of this plant are rich food sources of proteins, with a broad spectrum of amino acids, and various types of minerals and vitamins (Encina-Zelada et al., 2017). Recent data demonstrate that the seeds of quinoa consist of $14 \%$ proteins (Navarro-
Lisboa et al., 2017), but the protein content can be increased to $20 \%$, which has been reported for improved varieties (Giménez et al., 2016). Therefore, the high agronomic features and high nutritive values of quinoa prompted scientists and agronomists to focus their research efforts on this valuable plant (Betalleluz Pallardel et al., 2017). The most compelling characteristics of quinoa that makes it attractive for research is that it contains a high percentage of essential amino acids (48\%), particularly lysine $(6 \%)$ that is three times greater than in wheat kernels (Yazar and Çiğdem, 2014). Another interesting feature of quinoa is that it can grow in a variety of environmental conditions, and especially well in South America (Maliro et al., 2017). Also, this plant shows a broad range of tolerance to temperature conditions $\left(-4^{\circ} \mathrm{C}-38^{\circ} \mathrm{C}\right)$ and humidity (dry climates with $88 \%$ relative humidity), and thus it is distributed in the Andes in

\footnotetext{
* Corresponding author: Department of Horticultural Science, University of Tehran, Karaj, Iran; e-mail: mohsenhessami33@ut.ac.ir
} 
different agro-ecological zones. Furthermore, quinoa has a relative tolerance to drought stress and to the lack of soil moisture because of its low water requirement (Maliro et al., 2017). Quinoa can grow in a vast range of soils with a broad range of $\mathrm{pH}$. Interestingly, some genotypes of quinoa perform best under severe drought stress conditions, which suggests their heightened resistance to this factor (Paterson and Kolata, 2017). Due to its potential to provide sufficient food for countries suffering from food scarcities in the face of climate change, the Food and Agriculture Administration (FAO) designated 2013 the International Year of Quinoa (Yazar and Çiğdem, 2014). Importantly, in developed countries such as North America and European countries, the attention to healthy food including local organic produce and superfoods has increased exponentially in recent years and consumers are showing an increased interest in organic quinoa (Yazar and Çiğdem, 2014).

In order to enhance its agronomic features and promote the use of quinoa, several breeding programs have been conducted in different South American countries (Bazile et al., 2016; Jarvis et al., 2017; Murphy et al., 2016). One of the primary goals of these breeding programs was to eliminate saponins, triterpene glycosides (Hesami and Daneshvar, 2016a; Maliro et al., 2017; Paterson and Kolata, 2017) that are responsible for the bitterness of quinoa seeds (Paterson and Kolata, 2017). However, because quinoa is an inbred plant with some degree of cross-pollination, breeders are facing problems in maintaining the genetic purity of newly established varieties (Ana-Cruz et al., 2017). Such cross-pollination is most probably the reason why some quinoa varieties for example, Sajama, regain the potential to create saponins (Paterson and Kolata, 2017; Wu et al., 2017).

Vegetative propagation induced via in vitro cloning by providing a physical environment and a nutrition-sufficient medium could ensure the uniformity of quinoa (Hesami and Daneshvar, 2016a). In organ and callus cultures, the shoot formation usually leads to genetic alterations, while genetic characteristics of clones can be preserved by propagation via shoot tips or meristem cultures (Bhojwani and Dantu, 2013). Numerous studies on different plants such as Arachis hypogaea (Hsieh et al., 2017), Moringa oleifera (Avila-Treviño et al., 2017), Camellia oleifera (Li et al., 2016), Ficus religiosa L. (Hesami et al., 2017), Passiflora caerulea L. (Jafari et al., 2017), and Withania somnifera (Nayak et al., 2013) have indi- cated that cotyledonary node explants possess a great potential for shoot proliferation. However, to date there have been limited studies on applying in vitro methods on plants from Chenopodiaceae family. Most studies were conducted on Beta vulgaris (Taghipour et al., 2013; Yildiz et al., 2013), Spinacia (Al-Khayri et al., 1991; Shojaei et al., 2010; Usman et al., 2014), Atriplex (Mei et al., 1997; Nedjimi et al., 2006), and Chenopodium sp. (Burnouf-Radosevich and Paupardin, 1985; Eisa et al., 2005; Hesami and Daneshvar, 2016a).

The main reason for losses during in vitro culture is contamination by microorganisms such as bacteria, fungi, yeast, and viruses (Arab et al., 2014). The four most common sources of contamination are the external/internal plants, the air, the insufficiently sterilized nutrition media, and the inaccuracy of research workers (Arab et al., 2014; Bhojwani and Dantu, 2013). Therefore, maintaining sterile conditions in plant tissue cultures is of paramount importance, and it plays an essential role in the success of tissue culture procedures (Jafari et al., 2016). The first goal of every researcher in plant tissue cultures is to eliminate or to suppress contamination, which is being conducted in most cases via chemical sterilization (Bhojwani and Dantu, 2013).

Chemicals employed in sterilization of plant tissue cultures should be applicable, available, nontoxic, and cheap (Bhojwani and Dantu, 2013). The effective chemicals in the sterilization of the in vitro cultures are ones that are strong enough to inhibit and reduce the growth of microorganisms that have caused contamination and are capable of being used at the highest possible concentration without injuring the explants (Arab et al., 2014; Jafari et al., 2016).

Overall, determining the proper concentration and the best exposure time of the sterilant to limit explant injury is essential in plant tissue culture techniques (Bhojwani and Dantu, 2013). Therefore, this study aimed at determining the suitable concentration and exposure time of sodium hypochlorite solution for achieving the best sterilization protocol in plant tissue cultures of quinoa seeds. The proper balance of plant growth regulators for in vitro multiplication via cotyledonary node cultures of quinoa was also determined. The protocol developed for this study can help breeders in multiplying quinoa and maintaining the genetic uniformity of this valuable germplasm. 


\section{Materials and methods}

\section{Optimizing the sterilization protocol}

This study was conducted in the Department of Horticultural Science, University of Tehran, Karaj, Iran. The seeds were washed with tap water for 30 min and then cleaned with a liquid soap solution followed by washing with tap water. Further surface sterilization treatment was performed in a laminar air flow chamber. The seeds were surface sterilized with $70 \%$ aqueous ethanol for $15 \mathrm{sec}$ and then dipped into one of the five different concentrations of sodium hypochlorite including $5 \%, 10 \%$, $15 \%, 20 \%$, and $25 \%$ and for one of the three exposure times $(5,10$, and 15 minutes), giving a total of 18 treatment combinations. Afterward, the seeds were incubated on MS (Murashige and Skoog, 1962) medium. After 14 days of culturing, the efficiency of sodium hypochlorite concentrations and the exposure times on in vitro sterilization and seed germination efficiencies were determined.

\section{Media and culture conditions}

Murashige and Skoog (MS) medium was used in all experiments. The MS medium contained $3 \%(\mathrm{w} / \mathrm{v}) \mathrm{su}-$ crose, and $0.6 \%$ agar (Duchefa biochemie, the Netherlands). $\mathrm{pH}$ of the MS medium was adjusted to $5.8 \pm 2$ by using $1 \mathrm{~N} \mathrm{KOH}$ or $1 \mathrm{~N} \mathrm{HCl}$ before autoclaving at $121^{\circ} \mathrm{C}$ for $20 \mathrm{~min}$. All cultures were incubated at $25 \pm 2{ }^{\circ} \mathrm{C}$ for a 16-hour photoperiod accompanied by a light intensity of $65 \mu \mathrm{mol} \mathrm{m}{ }^{-2} \mathrm{~s}^{-1}$ provided by cool white, fluorescent tubes.

\section{Shoot proliferation}

Cotyledonary node segments were used as the source of explants for shoot proliferation. They were excised from 4-week-old seedlings grown under in vitro conditions. For a multiple shoot induction, the cotyledonary nodes $(5-10 \mathrm{~mm})$ were inoculated vertically on MS medium containing various concentrations and combinations of growth regulators. The MS media consisting of different concentrations of 6-benzylaminopurine (BAP) $(0.5-2.5 \mathrm{mg} / \mathrm{l})$, Kinetin $(\mathrm{KN})(0.5-2.5 \mathrm{mg} / \mathrm{l})$, and Thidiazuron (TDZ) $(0.1-0.5 \mathrm{mg} / \mathrm{l})$ and combinations of BAP $(2.0 \mathrm{mg} / \mathrm{l})$ with 1-naphthaleneacetic acid (NAA) (0.1-0.5 mg/l), and $\mathrm{KN}(0.5-2.5 \mathrm{mg} / \mathrm{l})$ were employed for shoot multiplication. Explants grown on MS medium without any plant growth regulator served as a control.
Shoot cultures were kept on fresh media by regular subculturing at 4 -week intervals. After 4 weeks of culturing, the efficiency of PGRs on shoot multiplication was evaluated by recording the frequency of responding explants, the number of shoots per explant, and the average shoot length.

\section{Statistical analysis}

The experiments were set out in a completely randomized design (CRD), and there were 10 replicates per each treatment, and each treatment was repeated in three sets. The data were analyzed by the Analysis of Variance (ANOVA) followed by the Duncan's multiple range test. The data analysis was performed using SAS version 9.3.

\section{Results and discussions}

Successful micropropagation of all plants depends on conditions of the initial plant material at the time of collection and removal of contaminating exogenous and endogenous microorganisms. Fungi and bacteria are the most common microorganisms to be found on or in plant tissues (Bhojwani and Dantu, 2013). Establishing a sterile in vitro culture is the first and most important step to achieve success in commercial micropropagation of plants (Arab et al., 2014).

A broad range of surface sterilants such as silver nitrate, hydrogen peroxide, ethanol, bromine water, antibiotics, and mercuric chloride are utilized for surface sterilization. However, sodium hypochlorite $(\mathrm{NaOCl})$ has been most broadly used in plant tissue cultures. Sodium hypochlorite is highly effective against all kinds of bacteria, fungi, and viruses (Bhojwani and Dantu, 2013). Moreover, sodium hypochlorite has strong oxidizing properties which make it highly reactive with amino acids, nucleic acids, amines, and amides (Jafari et al., 2016). The general reaction between amino acids and $\mathrm{NaOCl}$ produces the respective aldehyde, $\mathrm{NH}_{4} \mathrm{Cl}$, and $\mathrm{CO}_{2}$ (Wlodkowski and Rosenkranz, 1975).

No contamination was observed in sterilization treatments with $20 \%$ sodium hypochlorite for the 10 and 15 min immersion times and 25\% sodium hypochlorite for 5,10 , and 15 min immersion times (Table 1). The results showed that with increasing concentrations of sodium hypochlorite and immersion times, the percentage of contamination was reduced (Table 1). According 
Table 1. Effect of various concentrations of sodium hypochlorite and different immersion times on in vitro contamination of Chenopodium quinoa

\begin{tabular}{|c|c|}
\hline Treatments & Contamination [\%] \\
\hline \multicolumn{2}{|c|}{ Sodium hypochlorite concentration } \\
\hline $0 \%$ & $93.33 \mathrm{a}$ \\
\hline $5 \%$ & $52.22 \mathrm{~b}$ \\
\hline $10 \%$ & $32.22 \mathrm{c}$ \\
\hline $15 \%$ & $16.66 \mathrm{~d}$ \\
\hline $20 \%$ & $1.11 \mathrm{e}$ \\
\hline $25 \%$ & $0.00 \mathrm{f}$ \\
\hline \multicolumn{2}{|c|}{ Time } \\
\hline $5 \mathrm{~min}$ & $35.55 \mathrm{a}$ \\
\hline $10 \mathrm{~min}$ & $32.77 \mathrm{ab}$ \\
\hline $15 \min$ & $29.44 \mathrm{~b}$ \\
\hline \multicolumn{2}{|c|}{ Sodium hypochlorite concentration $\times$ tim } \\
\hline $0 \% \times 5 \min$ & 93.33 a \\
\hline $0 \% \times 10 \mathrm{~min}$ & $93.33 \mathrm{a}$ \\
\hline $0 \% \times 15 \mathrm{~min}$ & $93.33 \mathrm{a}$ \\
\hline $5 \% \times 5 \mathrm{~min}$ & $56.66 \mathrm{~b}$ \\
\hline $5 \% \times 10 \mathrm{~min}$ & $53.33 \mathrm{~b}$ \\
\hline $5 \% \times 15 \mathrm{~min}$ & $46.66 \mathrm{~b}$ \\
\hline $10 \% \times 5 \mathrm{~min}$ & $36.66 \mathrm{c}$ \\
\hline $10 \% \times 10 \mathrm{~min}$ & $33.33 \mathrm{~cd}$ \\
\hline $10 \% \times 15 \mathrm{~min}$ & 26.66 cde \\
\hline $15 \% \times 5 \mathrm{~min}$ & $23.33 \mathrm{de}$ \\
\hline $15 \% \times 10 \mathrm{~min}$ & 16.66 ef \\
\hline $15 \% \times 15 \mathrm{~min}$ & $10.00 \mathrm{fg}$ \\
\hline $20 \% \times 5 \mathrm{~min}$ & $3.33 \mathrm{~g}$ \\
\hline $20 \% \times 10 \mathrm{~min}$ & $0.00 \mathrm{~g}$ \\
\hline $20 \% \times 15 \mathrm{~min}$ & $0.00 \mathrm{~g}$ \\
\hline $25 \% \times 5 \mathrm{~min}$ & $0.00 \mathrm{~g}$ \\
\hline $25 \% \times 10 \mathrm{~min}$ & $0.00 \mathrm{~g}$ \\
\hline $25 \% \times 15 \mathrm{~min}$ & $0.00 \mathrm{~g}$ \\
\hline
\end{tabular}

Means in each column followed by the same letters are not significantly different according to DMRT at $P<0.05$

to the previous study, sodium hypochlorite was reported to be efficient in eliminating many types of bacteria; even in micromolar concentrations, it significantly reduced bacterial populations (Jafari et al., 2016; Nakagawara et al., 1998). It has also been reported that, when diluted with water, hypochlorite salts $\left[\mathrm{Ca}(\mathrm{OCl})_{2}, \mathrm{NaOCl}, \mathrm{LiOCl}\right.$, and $\mathrm{KOCl}]$ lead to the formation of $\mathrm{HClO}$. Also, the concentration of hypochlorite salts is negatively correlated with contamination which means that by increasing the concentration of hypochlorite salts, the level of contamination decreased significantly, perhaps in part due to the lethal DNA damage caused by sterilizing agents (Dukan et al., 1999; Wlodkowski and Rosenkranz, 1975).

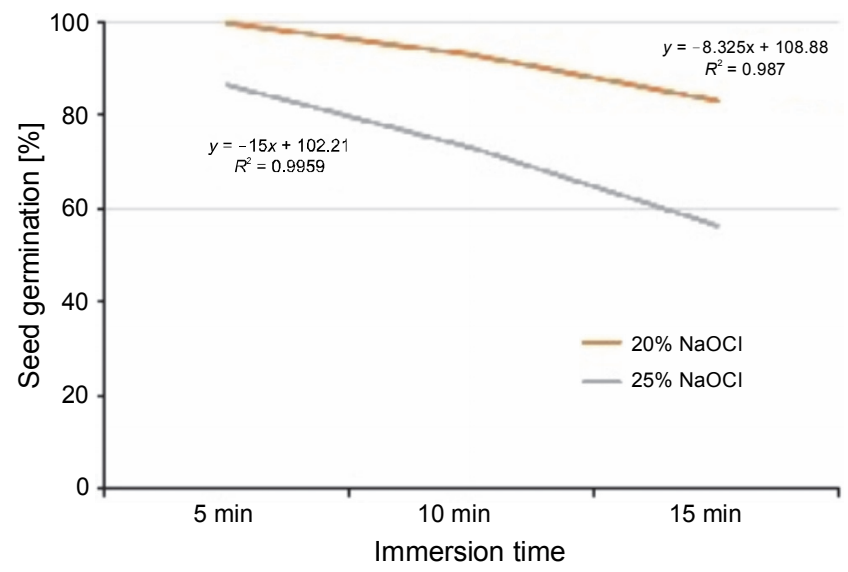

Fig. 1. Interaction of different $\mathrm{NaOCl}$ concentrations and immersion times on seed germination of Chenopodium quinoa

In this study, an increase in the concentration of sodium hypochlorite and immersion times had a negative effect on the seeds, resulting in development of a blackish color and lowering the germination rate (Fig. 1). The highest germination rate (100\%) was achieved in $20 \% \mathrm{NaOCl}$ after 5 min of immersion. With increase in the immersion time (15 $\mathrm{min}$ ), the seed germination rate decreased significantly (56.67\%). Therefore, it has been established that a longer immersion time exerts a negative impact on seed germination. Also, the seed germination rate decreased with the increase in $\mathrm{NaOCl}$ concentration but the trend was stronger under a high concentration of $\mathrm{NaOCl}$ than at low concentrations of this particular sterilant (Fig. 1). In in vitro seed germination, the growth of the seedlings and the viability of the tissues were negatively affected by $\mathrm{NaOCl}$ at high concentrations (Jafari et al., 2016), while it was ineffective in the sterilization of tissues or/and organs at low concentrations (Arab et al., 2014). The adverse effects of sodium hypochlorite concentration significantly increased by increasing the immersion times. Since the organogenesis potential of the tissue is negatively affected by higher concentrations and longer immersion times of the sterilants, as indicated also by other researches (Bhojwani and Dantu, 2013), the in vitro steri 


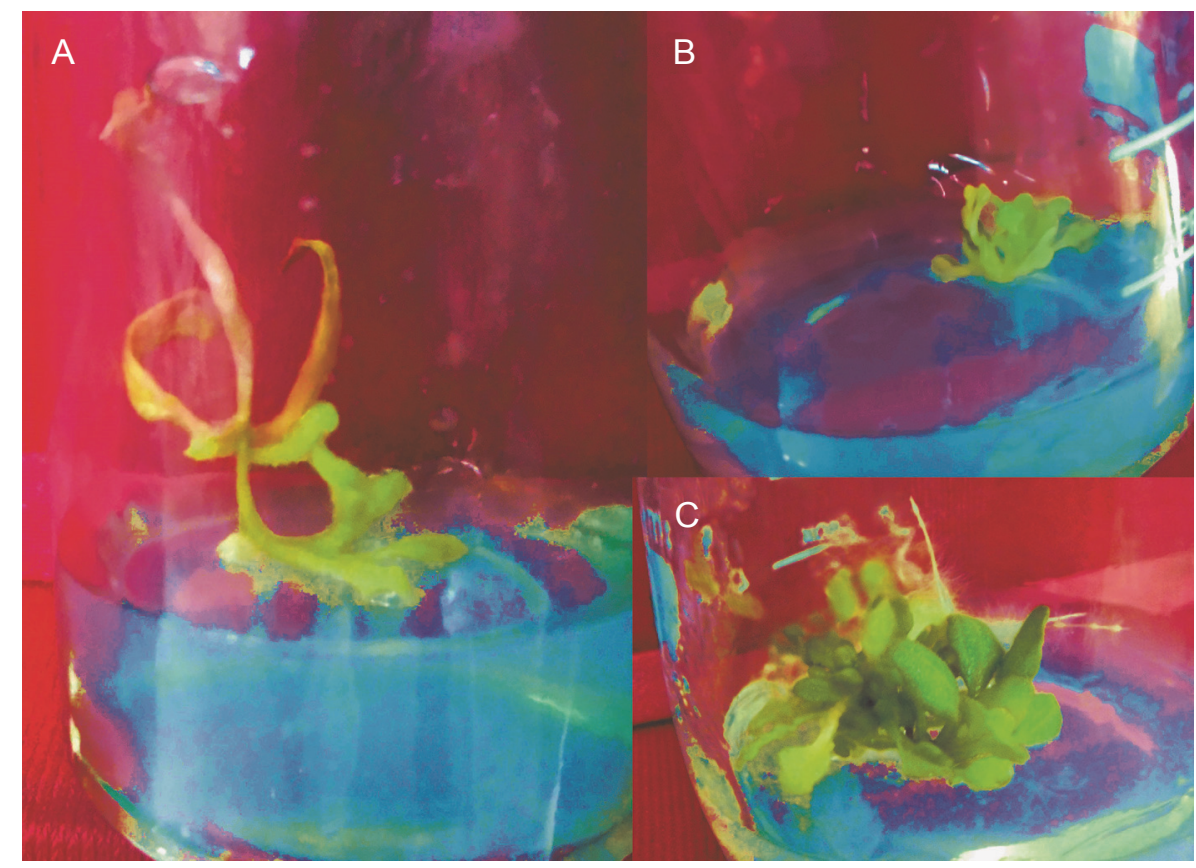

Fig. 2. In vitro shoot regeneration through direct organogenesis from seedling derived cotyledonary node segments of Chenopodium quinoa: A) seedling from an in vitro seed germination, B and C) shoot regeneration from a cotyledonary node segment on MS $+2.0 \mathrm{mg} / \mathrm{l} \mathrm{BAP}$ after 2 and 4 weeks, respectively

lization step should be performed for the shortest time and at the lowest sterilant concentration possible.

The aim of the study conducted by Telci and coworkers (2011) was to evaluate the effects of sodium hypochlorite solutions employed for the sterilization of seeds on the seedling growth of Lathyrus chrysanthus. They reported that the best results were achieved with $3.75 \% \mathrm{NaOCl}$ concentration and a 15 min application period for all parameters examined. Also, Telci and coworkers (2011) showed that seed-borne contamination increased consistently by decreasing the concentrations of sodium hypochlorite below $3.75 \%$ and 15 min sterilization time. Seed-borne contaminations dramatically decreased at $5.00 \% \mathrm{NaOCl}$ concentration while at this concentration, $\mathrm{NaOCl}$ showed negative effects on the seed embryo. When the $\mathrm{NaOCl}$ concentration increased from $3.75 \%$ to $5 \%$ for the 15 min application period, the seed germination decreased to $65.18 \%$. The seedling growth from the seeds sterilized with $3.75 \% \mathrm{NaOCl}$ concentration for $15 \mathrm{~min}$ had a higher growth rate than those sterilized with other $\mathrm{NaOCl}$ concentrations and application periods.

Many studies on Chenopodium spp. demonstrated a low survival and a low regeneration rate of Chenopodium spp., with visible abnormalities such as the yel- lowing and shading of leaves and showing signs of early senescence (Burnouf-Radosevich and Paupardin, 1985; Eisa et al., 2005; Hesami and Daneshvar, 2016a). The first and the most important factor in plant tissue cultures is the choice of effective explants (Mali and Chavan, 2016). Therefore, much attention was given to the analysis of using different parts of in vitro seedlings in plant tissue cultures as possible explants. For instance, shoot tips, hypocotyls segments, embryonal axis, and axenic leaves from in vitro grown seedling were used as explants in many studies conducted by different researchers to set applicable and effective protocols for many species (Eisa et al., 2005; Hesami and Daneshvar, 2016a, 2016b; Hesami et al., 2017; Hsieh et al., 2017; Jafari et al., 2017; Li et al., 2016; Mali and Chavan, 2016). This study indicated, for the first time, the usefulness of cotyledonary node segments obtained from axenic-seedlings as a source of explants for successful multiplication of quinoa (Fig. 2A). The reason for choosing cotyledonary node segments was that they developed easily into shoots while maintaining the genetic uniformity, without having any influence on the callus phase. Since indirect organogenesis methods through callus often lead to somaclonal variation, in order to achieve true to type plants, it is necessary to use direct 
Table 2. Effect of various concentrations and combinations of plant growth regulators on shoot proliferation from cotyledonary nodes of $C$. quinoa

\begin{tabular}{|c|c|c|c|c|c|c|}
\hline \multicolumn{4}{|c|}{ Plant growth regulators $[\mathrm{mg} / \mathrm{l}]$} & \multirow{2}{*}{$\begin{array}{l}\text { Shoot induction } \\
\text { frequency [\%] }\end{array}$} & \multirow{2}{*}{$\begin{array}{l}\text { Number of shoots } \\
\text { per explant }\end{array}$} & \multirow{2}{*}{$\begin{array}{l}\text { Shoots length } \\
{[\mathrm{cm}]}\end{array}$} \\
\hline BAP & $\mathrm{KN}$ & $\mathrm{TDZ}$ & NAA & & & \\
\hline- & - & - & - & $0.00^{\mathrm{k}}$ & $0.00^{\mathrm{p}}$ & $0.00^{p}$ \\
\hline 0.5 & - & - & - & $73.33^{\text {bcde }}$ & $1.73^{1}$ & $2.73^{\mathrm{k}}$ \\
\hline 1.0 & - & - & - & $80.00^{\text {abcd }}$ & $2.66^{\text {gh }}$ & $3.83^{\mathrm{e}}$ \\
\hline 1.5 & - & - & - & $83.33^{\mathrm{abc}}$ & $3.00^{\mathrm{f}}$ & $4.76^{\mathrm{c}}$ \\
\hline 2.0 & - & - & - & $93.33^{\mathrm{a}}$ & $4.96^{\mathrm{a}}$ & $4.83^{c}$ \\
\hline 2.5 & - & - & - & $56.66^{\text {fgh }}$ & $2.46^{\mathrm{i}}$ & $3.53^{f}$ \\
\hline- & 0.5 & - & - & $53.33^{\text {gh }}$ & $2.16^{\mathrm{jk}}$ & $2.90^{\mathrm{j}}$ \\
\hline- & 1.0 & - & - & $56.66^{\text {fgh }}$ & $2.26^{\mathrm{j}}$ & $3.36^{\text {gh }}$ \\
\hline- & 1.5 & - & - & $73.33^{\text {bcde }}$ & $2.70^{\mathrm{g}}$ & $5.10^{\mathrm{a}}$ \\
\hline- & 2.0 & - & - & $66.66^{\text {defg }}$ & $2.76^{\mathrm{g}}$ & $3.76^{\mathrm{e}}$ \\
\hline- & 2.5 & - & - & $43.33^{\mathrm{h}}$ & $1.73^{1}$ & $2.86^{\mathrm{jk}}$ \\
\hline- & - & 0.1 & - & $23.33^{\mathrm{ij}}$ & $1.13^{\mathrm{n}}$ & $1.26^{\mathrm{n}}$ \\
\hline- & - & 0.2 & - & $26.66^{\mathrm{i}}$ & $1.23^{\mathrm{n}}$ & $1.33^{\mathrm{mn}}$ \\
\hline- & - & 0.3 & - & $16.66^{\mathrm{ij}}$ & $1.53^{\mathrm{m}}$ & $1.56^{1}$ \\
\hline- & - & 0.4 & - & $13.33^{\mathrm{ijk}}$ & $1.43^{\mathrm{m}}$ & $1.43^{\mathrm{m}}$ \\
\hline- & - & 0.5 & - & $10.00^{\mathrm{jk}}$ & $0.96^{\circ}$ & $1.03^{\circ}$ \\
\hline 2.0 & - & - & 0.1 & $76.66^{\text {bcde }}$ & $2.53^{\mathrm{hi}}$ & $3.16^{\mathrm{i}}$ \\
\hline 2.0 & - & - & 0.2 & $86.66^{\mathrm{ab}}$ & $4.66^{\mathrm{b}}$ & $4.96^{\mathrm{b}}$ \\
\hline 2.0 & - & - & 0.3 & $83.33^{\mathrm{abc}}$ & $3.73^{c}$ & $4.33^{\mathrm{d}}$ \\
\hline 2.0 & - & - & 0.4 & $73.33^{\text {bcde }}$ & $3.33^{\mathrm{e}}$ & $3.83^{\mathrm{e}}$ \\
\hline 2.0 & - & - & 0.5 & $53.33^{\text {gh }}$ & $1.86^{1}$ & $3.26^{\mathrm{hi}}$ \\
\hline 2.0 & 0.5 & - & - & $63.33^{\text {efg }}$ & $3.33^{\mathrm{e}}$ & $3.43^{\mathrm{fg}}$ \\
\hline 2.0 & 1.0 & - & - & $70.00^{\text {cdef }}$ & $3.50^{d}$ & $3.83^{\mathrm{e}}$ \\
\hline 2.0 & 1.5 & - & - & $56.66^{\text {fgh }}$ & $2.66^{\text {gh }}$ & $3.13^{\mathrm{i}}$ \\
\hline 2.0 & 2.0 & - & - & $53.33^{\text {gh }}$ & $2.13^{\mathrm{jk}}$ & $2.76^{\mathrm{jk}}$ \\
\hline 2.0 & 2.5 & - & - & $43.33^{\mathrm{h}}$ & $2.06^{\mathrm{k}}$ & $3.76^{\mathrm{e}}$ \\
\hline
\end{tabular}

Means in each column followed by the same letters are not significantly different according to DMRT at $P<0.05$

organogenesis (Mali and Chavan, 2016). Thus, in this study, the cotyledonary node segments derived from seedlings were a preferred source of explants to use for shoot organogenesis, proliferation, and for achieving the maximum shoot elongation. Our results were completely in line with those of Alonso-Herrada and coworkers (2016) in Acaciella angustissima and Hsieh and coworkers (2017) in Arachis hypogaea L. The potential of regeneration from axenic cotyledonary node segments was investigated on MS medium consisting of different plant growth regulators (Table 2). Without considering the concentration and types of PGRs in MS medium, within 2 weeks of inoculation, shoots regenerated from the explants. After 2 weeks of culture on MS medium supplemented with $2.0 \mathrm{mg} / \mathrm{l} \mathrm{BAP}$, a minimum of two shoots were produced by each explant (Fig. 2B). On MS medium without any PGRs, no shoot formation was observed. The percentage of response varied in explants grown on media supplemented with different types and concentrations of growth regulators. Based on our re- 
sults, BAP performed better in comparison with other PGRs. At $2 \mathrm{mg} / \mathrm{l}$ BAP concentration, a 93.33\% explant response, an average of $4.83-\mathrm{cm}$ shoot length, and 4.96 shoot numbers per explant were obtained (Table 2 and Fig. 2C). The MS medium containing KN or TDZ had a low shoot frequency, and explants grown on these media produced fewer shoots per explants, with $73.33 \%$ and $26.66 \%$ explant response for $\mathrm{KN}$ and TDZ, respectively (Table 2 ).

Similar to our results, many studies on different species such as Chenopodium quinoa (Burnouf-Radosevich and Paupardin, 1985; Hesami and Daneshvar, 2016a); Cucumis trigonus (Mali and Chavan, 2016); Leptadenia reticulata (Patel et al., 2014); Beta vulgaris (Yildiz et al., 2013); and Populus euphratica (Cai et al., 2015) demonstrated the superiority of BAP in shoot multiplication and shoot organogenesis, in comparison with other types of cytokinins.

According to this study, MS medium supplemented with $1.5 \mathrm{mg} / \mathrm{KN}$ induced the production of the longest shoots $(5.1 \mathrm{~cm})$ after 30 days of culture (Table 2). Gnanaraj and coworkers (2012) reported the promotive effect of KN on shoot elongation in Achyranthes bidentata and Achyranthes aspera. In the presence of BAP, multiple buds were produced. It has been established that cytokinins stimulate the growth of multiple buds from dormancy, promote shoot induction, and overcome apical dominance (Mali and Chavan, 2016).

Increasing BAP concentrations up to $2 \mathrm{mg} / \mathrm{l}$ led to a significant increase in the percentage (93.33\%) of shoot multiplications. However, with an increase in the TDZ concentration beyond $0.5 \mathrm{mg} / \mathrm{l}$, the capability of shoot regeneration went down gradually. TDZ, above $0.5 \mathrm{mg} / \mathrm{l}$, induced abnormal swelling. The shoot formation was induced as seen by the appearance of green buds, which however failed to convert into shoots.

The combination of $2 \mathrm{mg} / \mathrm{l} \mathrm{BAP}$ with $1 \mathrm{mg} / \mathrm{l} \mathrm{KN}$ stimulated the growth of 3.5 shoots per explant on average, with the average shoot length of $3.83 \mathrm{~cm}$. This combination of PGRs induced shoots at the rate of $70 \%$ (Table 2). Mali and Chavan (2016) reported a synergetic effect of $\mathrm{KN}$ and BAP on shoot induction in Cucumis trigonus. According to our study, TDZ showed a lower shoot proliferation potential than other treatments such as BAP and $\mathrm{KN}$, which is in contrast with many studies on various species such as Ziziphus jujuba (Feng et al., 2010), Cucumis trigonus (Mali and Chavan, 2016), and
Ficus religiosa (Siwach and Gill, 2011). The first reason for a low shoot proliferation in a medium supplemented with TDZ may be due to the dual auxin- and cytokininlike activities of the TDZ (Mali and Chavan, 2016) that might cause an increase in the levels of internal auxins (Bhojwani and Dantu, 2013). In culture media, cytokinins alone or in combination play an important role in shoot regeneration in numerous species (Bhojwani and Dantu, 2013; Hesami and Daneshvar, 2016a; Hsieh et al., 2017; Mali and Chavan, 2016).

The MS medium containing a combination of NAA and BAP induced the highest frequency of shoot multiplication. The synergistic effect was found to be best at a combination of $0.2 \mathrm{mg} / 1 \mathrm{NAA}$ and $2 \mathrm{mg} / \mathrm{l} \mathrm{BAP}$ for shoot regeneration from explants (4.66 shoots/explants) with the shoot formation at the highest percentage (86.66) off. Our results are in agreement with those of Hesami and Daneshvar (2016a) in Chenopodium quinoa, Mali and Chavan (2016) in Cucumis trigonus, and Yildiz et al. (2013) in Beta vulgaris.

\section{Conclusions}

Contamination with microorganisms hinders the growth of micropropagated plants because the nutrients contained in the media serves as a source of energy for these microorganisms. To avoid this, and to ensure proper growth and development of plants, the sterilization of explants must be done. Our results show that a low concentration of sodium hypochlorite with longer exposure times ensures good results and increases seed germination rates of Chenopodium quinoa. Also, the present study illustrates an effective, prolific, and cost-efficient system of in vitro organogenesis of quinoa allowing to induce direct regeneration with the cotyledonary node explants obtained from axenic in vitro seedlings. Direct organogenesis, without becoming involved in the callus phase, limits the chance of somaclonal variations. In this way, a direct organogenesis method ensures the genetic uniformity of in vitro propagated plants. This protocol has a high potential and may be applied to this highly valuable plant to obtain a large number of plantlets in a short time. Finally, this protocol can be used for breeding programs. 


\section{References}

Al-Khayri J.M., Huang F.H., Morelock T.E. (1991) Regeneration of spinach from leaf callus. HortScience 26: 913-914.

Alonso-Herrada J., Rico-Reséndiz F., Campos-Guillén J., Guevara-González R.G., Torres-Pacheco I., Cruz-Hernández A. (2016) Establishment of in vitro regeneration system for Acaciella angustissima (Timbe) a shrubby plant endemic of México for the production of phenolic compounds. Ind. Crops Prod. 86: 49-57.

Ana-Cruz M.C., Helena M.E., Yacenia M.C. (2017) Molecular characterization of Chenopodium quinoa Willd. using inter-simple sequence repeat (ISSR) markers. Afr. J. Biotech. 16: 483-489.

Arab M.M., Yadollahi A., Hosseini-Mazinani M., Bagheri S. (2014) Effects of antimicrobial activity of silver nanoparticles on in vitro establishment of $G \times N 15$ (hybrid of almond $\times$ peach) rootstock. J. Genet. Eng. Biotech. 12: 103-110.

Avila-Treviño J., Muñoz-Alemán J., Pérez-Molphe-Balch E., Rodríguez-Sahagún A., Morales-Domínguez J. (2017) In vitro propagation from bud and apex explants of Moringa oleifera and evaluation of the genetic stability with RAMP marker. South Afr. J. Bot. 108: 149-156.

Bazile D., Pulvento C., Verniau A., Al-Nusairi M.S., Ba D., Breidy J., Hassan L., Mohammed M.I., Mambetov O., Otambekova M. (2016) Worldwide evaluations of quinoa: Preliminary results from post international year of quinoa FAO projects in nine countries. Front. Plant Sci. 7.

Betalleluz Pallardel I., Inga M., Mera L., Pedreschi R., Campos D., Chirinos R. (2017) Optimisation of extraction conditions and thermal properties of protein from the Andean pseudocereal cañihua (Chenopodium pallidicaule Aellen). International J. Food Sci. Technol. 52: 1026-1034.

Bhojwani S.S., Dantu P.K. (2013) Micropropagation. [in:] Plant tissue culture: an introductory text. Ed. Bhojwani S.S., Dantu P.K. Springer, New Delhi: 245-274.

Burnouf-Radosevich M., Paupardin C. (1985) Vegetative propagation of Chenopodium quinoa by shoot tip culture. Amer. J. Bot. 278-283.

Cai Z., Jing X., Tian X., Jiang J., Liu F., Wang X. (2015) Direct and indirect in vitro plant regeneration and the effect of brassinolide on callus differentiation of Populus euphratica Oliv. South Afr. J. Bot. 97: 143-148.

Dukan S., Belkin S., Touati D. (1999) Reactive oxygen species are partially involved in the bacteriocidal action of hypochlorous acid. Arch. Biochem. Biophys. 367: 311-316.

Eisa S., Koyro H., Kogel K., Imani J. (2005) Induction of somatic embryogenesis in cultured cells of Chenopodium quinoa. Plant Cell Tissue Organ Cult. 81: 243-246.

Encina-Zelada C., Cadavez V., Pereda J., Gómez-Pando L., SalváRuíz B., Teixeira J.A., Ibañez M., Liland K.H., GonzalesBarron U. (2017) Estimation of composition of quinoa (Chenopodium quinoa Willd.) grains by Near-Infrared Transmission spectroscopy. LWT-Food Sci. Technol.

Feng J.-C., Yu X., Shang X., Li J., Wu Y. (2010) Factors influencing efficiency of shoot regeneration in Ziziphus jujuba Mill. 'Huizao’. Plant Cell Tissue Organ Cult. 101: 111-117.

Giménez M., Drago S., Bassett M., Lobo M., Sammán N. (2016) Nutritional improvement of corn pasta-like product with broad bean (Vicia faba) and quinoa (Chenopodium quinoa). Food Chem. 199: 150-156.

Gnanaraj W.E., Marimuthu J., Mohanamathi R., Subramanian K.M. (2012) In vitro clonal propagation of Achyranthes aspera L. and Achyranthes bidentata Blume using nodal explants. Asian Pacific J. Tropic. Biomed. 2: 1-5.

González-Teuber M., Vilo C., Bascuñán-Godoy L. (2017) Molecular characterization of endophytic fungi associated with the roots of Chenopodium quinoa inhabiting the Atacama Desert, Chile. Genomics Data 11: 109-112.

Hesami M., Daneshvar M.H. (2016a) Development of a regeneration protocol through indirect organogenesis in Chenopodium quinoa Wild. Indo-Am. J. Agric. Vet. Sci. 4: 25-32.

Hesami M., Daneshvar M.H. (2016b) Regeneration from Callus which is Produced from Cotyledon of Antirrhinum majus. Indo-Am. J. Agric. Vet. Sci. 4: 20-24.

Hesami M., Daneshvar M.H., Lotfi A. (2017) In vitro shoot proliferation through cotyledonary node and shoot tip Explants of Ficus religiosa L. Plant Tissue Cult. Biotech. 27: 85-88.

Hsieh Y.F., Jain M., Wang J., Gallo M. (2017) Direct organogenesis from cotyledonary node explants suitable for Agrobacterium-mediated transformation in peanut (Arachis hypogaea L.). Plant Cell Tissue Organ Cult. 128: 161-175.

Hu Y., Zhang J., Zou L., Fu C., Li P., Zhao G. (2017) Chemical characterization, antioxidant, immune-regulating and anticancer activities of a novel bioactive polysaccharide from Chenopodium quinoa seeds. Intern. J. Biol. Macromol. 99: 622-629.

Jafari M., Daneshvar M.H., Lotfi-Jalalabadi A. (2016) Control of in vitro Contamination of Passiflora caerulea by Using of Sodium Hypocholorite. Indo-Am. J. Agric. Vet. Sci. 4: 8-15.

Jafari M., Daneshvar M.H., Lotfi A. (2017) In vitro shoot proliferation of Passiflora caerulea L. via cotyledonary node and shoot tip explants. BioTechnologia 98: 113-119.

Jarvis D.E., Ho Y.S., Lightfoot D.J., Schmöckel S.M., Li B., Borm T.J., Ohyanagi H., Mineta K., Mitchell C.T., Saber N. (2017) The genome of Chenopodium quinoa. Nature 542: 307-312.

Li Z., Tan X., Liu Z., Lin Q., Zhang L., Yuan J., Zeng Y., Wu L. (2016) In vitro propagation of Camellia oleifera Abel. Using hypocotyl, cotyledonary node, and radicle explants. HortSci. 51: 416-421.

Mali A.M., Chavan N.S. (2016) In vitro rapid regeneration through direct organogenesis and ex-vitro establishment of Cucumis trigonus Roxb. - an underutilized pharmaceutically important cucurbit. Industr. Crops Prod. 83: 48-54.

Maliro M., Guwela V.F., Nyaika J., Murphy K. (2017) Preliminary studies of the performance of quinoa (Chenopodium quinoa Willd.) genotypes under irrigated and rainfed conditions of central Malawi. Front. Plant Sci. 8: 227-232. 
Mei B., No E., McWilliams E., Gould J., Newton R. (1997) In vitro regeneration of fourwing saltbush [Atriplex canescens (Pursh) Nutt.J. J. Range Manag. 413-418.

Murphy K.M., Bazile D., Kellogg J., Rahmanian M. (2016) Development of a worldwide consortium on evolutionary participatory breeding in Quinoa. Front. Plant Sci. 7: 1-8.

Nakagawara S., Goto T., Nara M., Ozawa Y., Hotta K., Arata Y. (1998) Spectroscopic characterization and the $\mathrm{pH}$ dependence of bactericidal activity of the aqueous chlorine solution. Analyt. Sci. 14: 691-698.

Navarro-Lisboa R., Herrera C., Zúñiga R.N., Enrione J., Guzmán F., Matiacevich S., Astudillo-Castro C. (2017) Quinoa proteins (Chenopodium quinoa Willd.) fractionated by ultrafiltration using ceramic membranes: the role of $\mathrm{pH}$ on physicochemical and conformational properties. Food Bioprod. Proces. 102: 20-30.

Nayak S., Kumar S., Satapathy K., Moharana A., Behera B., Barik D., Acharya L., Mohapatra P., Jena P., Naik S. (2013) In vitro plant regeneration from cotyledonary nodes of Withania somnifera (L.) Dunal and assessment of clonal fidelity using RAPD and ISSR markers. Acta Physiol. Plant. 35: 195-203.

Nedjimi B., Daoud Y., Touati M. (2006) Growth, water relations, proline and ion content of in vitro cultured Atriplex halimus subsp. schweinfurthii as affected by $\mathrm{CaCl2}$. Commun. Biometry Crop Sci. 1: 79-89.

Patel A.K., Agarwal T., Phulwaria M., Kataria V., Shekhawat N. (2014) An efficient in vitro plant regeneration system from leaf of mature plant of Leptadenia reticulata (Jeewanti): a life giving endangered woody climber. Industr. Crops Prod. 52: 499-505.

Paterson A.H., Kolata A.L. (2017) Genomics: Keen insights from quinoa. Nature 542: 300-302.

Shojaei T.R., Salari V., Ramazan D., Ehyaei M., Gharechahi J., Chaleshtori R.M. (2010) The effect of plant growth regulators, explants and cultivars on spinach (Spinacia oleracea L.) tissue culture. Afr. J. Biotechnol. 9: 4179-4185.
Siwach P., Gill A.R. (2011) Enhanced shoot multiplication in Ficus religiosa $L$. in the presence of adenine sulphate, glutamine and phloroglucinol. Physiol. Mol. Biol. Plants. 17: 271.

Sosa Zuniga V., Brito V., Fuentes F., Steinfort U. (2017) Phenological growth stages of quinoa (Chenopodium quinoa) based on the BBCH scale. Annals Appl. Biol.

Taghipour F., Janalizadeh N., Eshrati M., Hassanzadeh T., Huyop F. (2013) Callus induction and shoot organogenesis in two sugar beet (Beta vulgaris L.) breeding lines in vitro cultured. Biotechnology 12: 168-175.

Telci C., Yildiz M., Pelit S., Onol B., Erkilic E.G., Kendir H. (2011) The effect of surface-disinfection process on dormancy-breaking, seed germination, and seedling growth of Lathyrus chrysanthus Boiss. under in vitro conditions. Propagat. Ornament. Plants 11: 10-16.

Usman M., Noureen S., Fatima B., Zaman Q. (2014) Long days foster callogenesis in spinach and lettuce cultivars. J. Anim. Plant Sci. 24: 585-591.

Wlodkowski T.J., Rosenkranz H.S. (1975) Mutagenicity of sodium hypochlorite for Salmonella typhimurium. Mutat. Res. Environ. Mutagen. Related Subj. 31: 39-42.

Wu G., Ross C.F., Morris C.F., Murphy K.M. (2017) Lexicon development, consumer acceptance, and drivers of liking of quinoa varieties. J. Food Sci. 82: 993-1005.

Yazar A., Çiğdem İ. (2014) A New crop for salt affected and dry agricultural areas of Turkey: quinoa (Chenopodium quinoa Willd.). Türk Tarım ve Doğa Bilimleri. 7: 1440 -1446 .

Yildiz M., Alizadeh B., Beyaz R. (2013) In vitro explant growth and shoot regeneration from petioles of sugar beet (Beta vulgaris L.) lines at different ploidy levels. J. Sugar Beet Res. 50: 22-36. 